\title{
Development of Physical Activity Play Management to Improve Prosocial Behavior
}

\author{
Pramono, Nurhasan, Nining Widyah Kusnanik, Sudarsini
}

\begin{abstract}
Prosocial behavior reflects a child's concern or attention to others, for example, by helping, entertaining, or just smiling at another child. This activity found that such caring behavior in response to other people's emotional changes was predicted by the quality of relationship between a teacher and a child. The purpose of this study is to develop a play management to improve prosocial behavior in early childhood. This study used research design adapted from the Educational Research and Development model. The assessment of experts (validators) about play management is easily understood by the teacher. Games 1 to 6 , from all 6 questions, 4 questions in the very valid category $66.67 \%, 2$ questions in the valid category $33.33 \%$ and 0 question in the invalid category $0 \%$. The evaluation of the experts (validators) about the evaluation tools of prosocial behavior is appropriate to be used for kindergarten students aged 5-6 years. Games 1 to 9, from 9 questions,6 questions in the very valid category $77.78 \%$, 2 questions in the valid category $22.22 \%$ and 0 questions in the invalid category $0 \%$.
\end{abstract}

Index Terms: prosocial, play management, empathy.

\section{INTRODUCTION}

The social development of children who get great attention from early childhood educators is an aspect of moral development that is better known today as prosocial behavior. Prosocial behavior includes such as empathy, where children express love by entertaining or pleasing someone in distress or by expressing the feelings of other children during interpersonal conflict, generosity in which children share or give their own to someone, cooperation where children take turns voluntary or fulfilling requests cheerfully and caring, where children help others in need or to complete a task.

All of these are some traits that help people to get along in society, motivate people to interact with each other, and help make people social. Early childhood is not alone in the world. They are part of a family, a group of relatives, neighbors, communities, countries and the world. To become an integrated member of the human tribe, early childhood needs to learn the rules of behavior from the beginning.

In the process of treating social behavior, it should take place at home, and take place informally. The parents should realize they teach children to behave pro or anti socially. Early childhood absorbs everything that happens around them. The opinion of Riller San Juan, Klinger, Raminger (2008) shows that "children are more accepted by peers when their parents are warm, responsive and in harmony with their

Revised Manuscript Received on September 22, 2019.

Pramono, Malang State University, Email: pramono.fip@um.ac.id

Nurhasan, Surabaya State University

Nining Widyah Kusnanik, Surabaya State University

Sudarsini, Malang State University children". The opposite is true if children are more difficult to get along with peers when interactions with older people are hostile and overly restrictive. The purpose of this study is to develop play management to improve prosocial behavior in early childhood

\section{LiterATURE REVIEW}

Prosocial behavior that can be exemplified both at home and at school should be aware of the treatment taught in examples of behavior, which is absorbed so easily by early childhood, especially in emotional situations ${ }^{3}$. Children also observe behavior by methods apart from examples both at home and at school. Caregiving is important in personal development in the process of socializing children and adolescents, but aggressive behavioral social factors explain about $30 \%$ of variance which presents the need to learn psychological, cognitive and emotional processes involved in aggressive and violent behavior ${ }^{7}$.

The prosocial behavior reflects concern or attention from a child to another child, for example by helping, entertaining, or just smiling at another child. This activity found that such caring behavior in response to other people's emotional changes was predicted by the quality of teacher and child relationships. The better the relationship between the teacher and child affects the prosoial behavior of a child towards his peers. The development of a child prosocial behavior must be given through stimulation from an early age, so that,he will get used to behaving well and can influence their future lives. Prosocial behavior is the most important thing for everyone, including early childhood. Early childhood is the most critical period of child development.

Social-emotional and cognitive development took place rapidly during this formative period, with more intense critical transitions. In fact, exposure to the outside environment encourages intellectual growth and cognitive learning which are also related to broader experience. Therefore, the learning environment through play needs to be brought into the lives of all children together with the principles and practices of local communities ${ }^{2}$.

Empathy is the ability to understand other people's thoughts, feel emotions outside of ourselves, and respond with kindness, and care about the suffering of others ${ }^{11}$ Empathy, generosity, cooperation, caring, how the teacher of PAUD (Pendidikan Anak Usia Dini/Preschool Education) teaches these behaviors. Empathy is the ability to feel as perceived by others. The foundation for exploring the relationship between secure attachment and empathy, discussing potential mediation 
mechanisms, and presenting a theoretical model of empathic development ${ }^{11}$. Measuring the attention of other people's needs and situations, as evidenced by perspective taking and mutual cooperation. Other studies rely on the same self-report data suggesting that women may be more empathic than men ${ }^{8}$. Neuroscience research on affective development with children and adults shows that the affective, cognitive and regulatory aspects of empathy involve interaction, but some do not overlap, on neural circuits. Empathy is a complex social phenomenon that has many faces that ${ }^{8}$ have fascinated scholars from various fields and services for centuries ${ }^{6}$. One of the major conceptual findings of Singer et al.'s "seed study", which was probably also one of the reasons it had sucha strong impact, was the observation that empathy recruits sim-ilar neural networks as the direct experience of the emotion oneis showing empathy for ${ }^{6}$.

Empathy is sometimes difficult for some children to feel when they are in conflict with others. But teachers can actually teach children to realize what other children feel to turn this conflict into a positive feeling. This new approach to conflict resolution is called "changing the conflict of self-esteem of others with management playing". Most conflicts in early childhood revolve around ownership disputes. A child wants something that is being played by another child, or a child who takes something from another child. Most of these conflicts are minor disturbances in play, resolved by the children themselves. Sometimes conflict becomes so intense that parents and teachers must intervene especially when fighting, throwing things, or crying. Playing activities in the learning process in early childhood is an absolute requirement, because for early childhood learning is playing and playing is learning. Teachers must design creatively play activities to develop children's physical activities both in the classroom and outside the classroom. Play is one of the important components of a child's life and it is a major activity that promotes children's imagination and creativity Children can learn the basic and social skills and develop through play ${ }^{9}$. Children need to have an opportunity to explore some materials and play objects and this opportunity also advances children 's creativity ${ }^{9}$. The criteria used by children reveal that they are called fun activities they are involved in and directed to play, and those who are involved in activities, learning or work ${ }^{10}$. The game is a source of fun and entertainment for children ${ }^{5}$.Implicit learning is the ability to acquire a new skill without a corresponding increase in knowledge about the skill, i.e. individuals are not aware of the regularities governing the skill $^{4}$.

\section{Methodology}

This research used research design adapted from the Educational Research and Development (R \& D) model which refers to Borg \& Gall (1989: p624), Research and Development (R \& D) refers to the ADDIE development model which consists of five stages namely analysis, design, development, implementation and evaluation. Therefore, the developer will explain the results of the development of the model according to the following ADDIE stages:(1) Research and information collecting). (2) planning. (3) develop

preliminary form of product). (4) preliminaryfield testing. (5) main product revition. (6) main field testing. (7) operational product revision. (8) operational field testing. (9) final product revision. (10) dissemination and implementation.

The procedure of development research used in this study can be done more simply involving the main steps which include:

a) Conduct research and data / information collection with literature studies, observations, discussions, and field studies, as the basis for developing play management prototypes to improve prosocial behavior in children aged 5-6 years.

b) Conducting planning, formulating the objectives to be achieved and the steps of the study including the development and design of feasibility tests on management play to improve prosocial behavior in children aged 5-6 years.

c) Development of initial product design management plays to improve prosocial behavior in children aged 5-6 years to be tested, including materials / learning resources, instruments needed to be evaluated by 2 early childhood learning experts, 2 motoric experts, and 1 expert Evaluation instrument.

d) Validate the design of the initial product before testing (instrument use test).

e) Design revisions after expert validation.

f) Initial field trials (small groups) using 1 class of B group conducted to collect data. At this stage the data is collected through interviews, observations and questionnaires, then the data is analyzed to find its effectiveness.

g) Revise the initial product based on the results of a small group trial.

h) Conduct field trials (large group test) with the number of subjects 2 classes in group B of TK (Taman Kanak-kanak/Kindergarten).

i) Test the effectiveness of the model using action research.

\section{RESULTS AND FINDING}

Based on data from the trial study "development of play management to improve children's prosocial behavior at group B of UM Lab Kindergarten Malang city", it will be presented data from expert reviews, results of small group trials, and results of large group field trials. Data from the expert review were obtained from the evaluation of 2 early childhood education experts and a motoric expert. Data from the results of the review of small group trials and large group field tests were obtained from the implementation of learning activities of group B of UM Lab Kindergarten Malang city. (1) Data management of experts' evaluation this research and development was evaluated by three experts: 2 experts in learning PAUD and 2 experts in motoric learning, in the form of quantitative and qualitative data. 
a) Expert validation in the form of concepts, principles, objectives, characteristics, implementation instructions before the trial is presented in Table 1. Expert Validation Data TABLE 1. EXPERT VALIDATION DATA

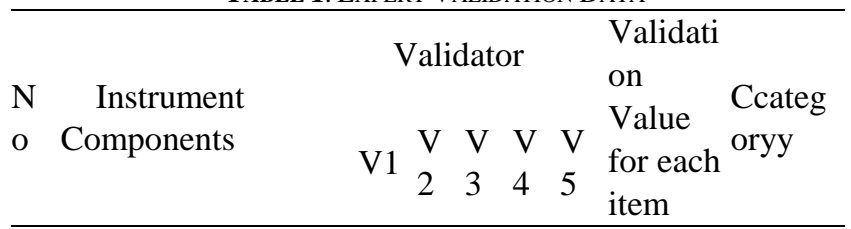

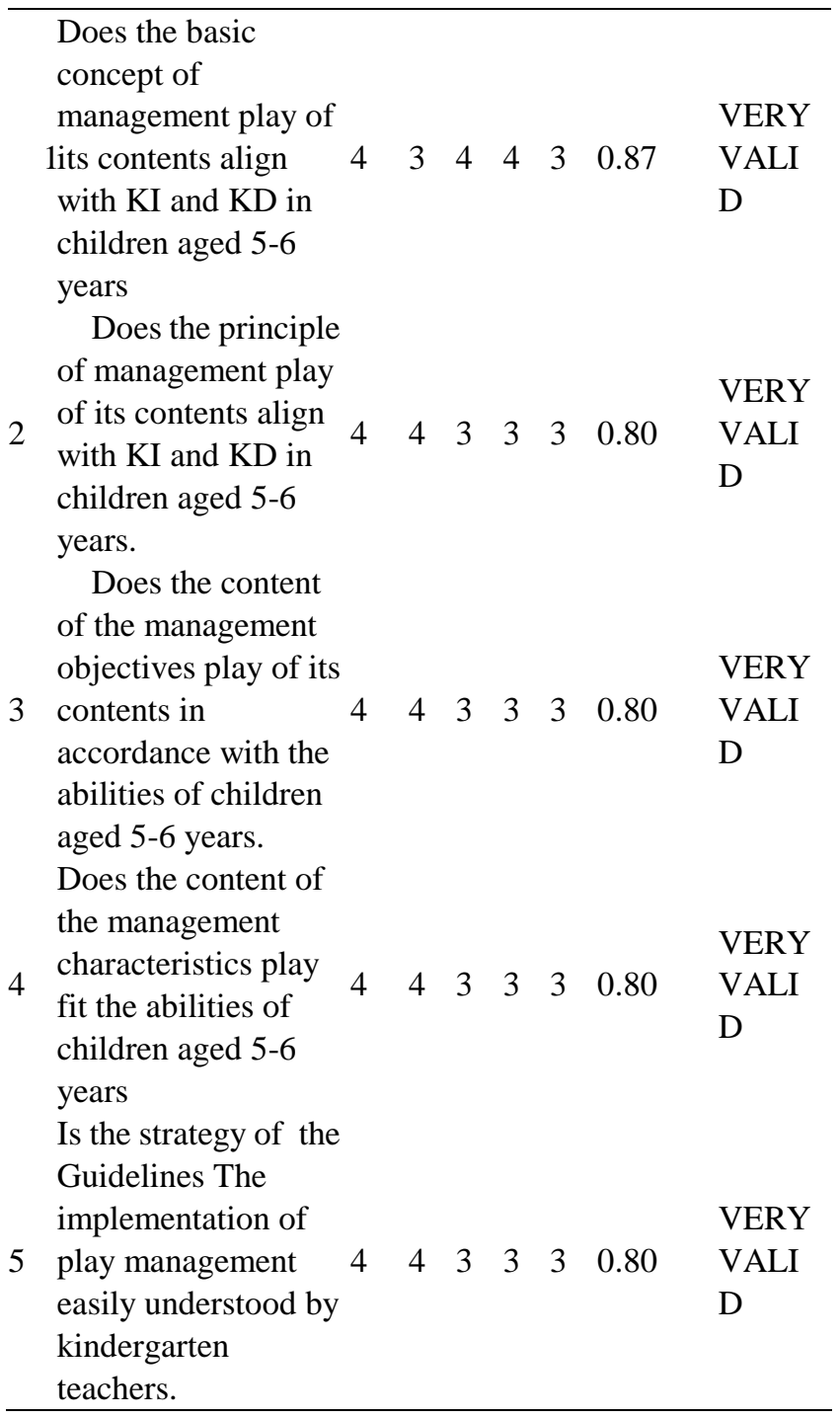

$\mathrm{V}=$ Validator

Based on the assessment of the experts obtained the aspect value The basic concept of management play is in harmony with KI and KD in children aged 5-6 years with a value of 0.87 with avery valid category. The principle of management play is in harmony with $\mathrm{KI}$ and KD in children aged 5-6 years with a value of 0.8 categories is very valid. The purpose of management play is in accordance with the ability of children aged 5-6 years with a value of 0.80 with a very valid category. The characteristics of playing management are in accordance with the ability of children aged 5-6 years with the value of 0.80 with a very valid category. The instructions of play management implementation is easily understood by kindergarten teachers with a value of 0.80 with a very valid category. This shows that the level of validity of concepts, principles, objectives, characteristics, implementation guidelines for early childhood is very valid categories. b) Expert validation in the form of game management to improve prosocial behavior before the trial is shown in Table 2. Expert Validation Data

TABLE 2. EXPERT VALIDATION DATA

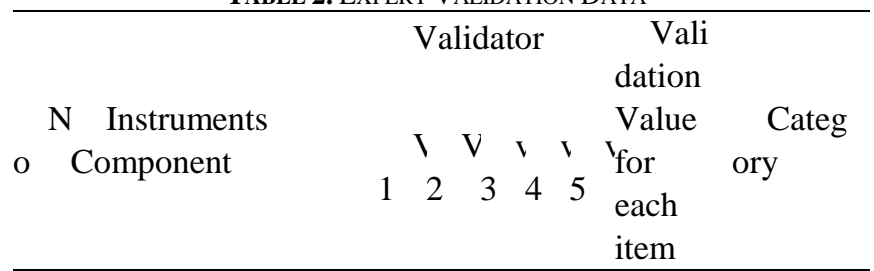

Are the types of

games easily

understand by

1 kindergarten

VER

1 teachers. Movement

$44 \cong 230.80 \mathrm{Y}$

to throw and catch

VALID

the ball soaring in

pairs.

Group walking

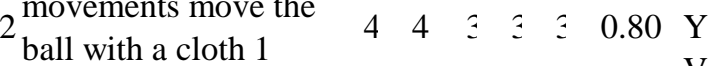

meter wide.

Group walking

3 movements move the $44 \div 2 \div 0.80 \mathrm{Y}$ ball with a pipe.

The movement ran

${ }_{4}$ back and forth

pairing geometric

$4322 \div 0.73 \underset{\mathrm{UGH}}{\mathrm{ENO}}$

VALID

VER

shapes.

Movement to

ball along the ground $\begin{array}{lllllll}4 & 3 & 2 & 4 & 0.80 & \mathrm{Y}\end{array}$

in pairs.

VALID

Group standing

movements move the

6 ball from the top of

the head, right side,

$4322 \div 0.73 \underset{\mathrm{UGH}}{\mathrm{ENO}}$

left and bottom side.

TABLE 3. PERCENTAGE OF EXPERT VALIDATION DATA IN THE FORM OF GAME MANAGEMENT TO IMPROVE PROSOCIAL BEHAVIOR BEFORE BEING TESTED

Number of Category

Question Items $\quad$ Very Valid Valid Not Valid

$\begin{array}{llll}6 & 4 & 2 & 0\end{array}$

$\begin{array}{llll}\text { Percentage } & 66.67 & 33.33 & 0.00\end{array}$

Based on the assessment of the experts (validators) about the management of play, it is easy to understood by the teacher, Games 1 to 6 , from 6 questions in the very validcategory, 4 questions $66.67 \%$ in the valid category, 2 questions $33.33 \%$ and in the category invalid 0 questions $0 \%$.

c) Expert evaluationValidation of Prosocial behavioral assessments are appropriate to be used in kindergarten students ages 4-5 years before the trial is shown in Table 4. Expert Validation Data

Published By: 


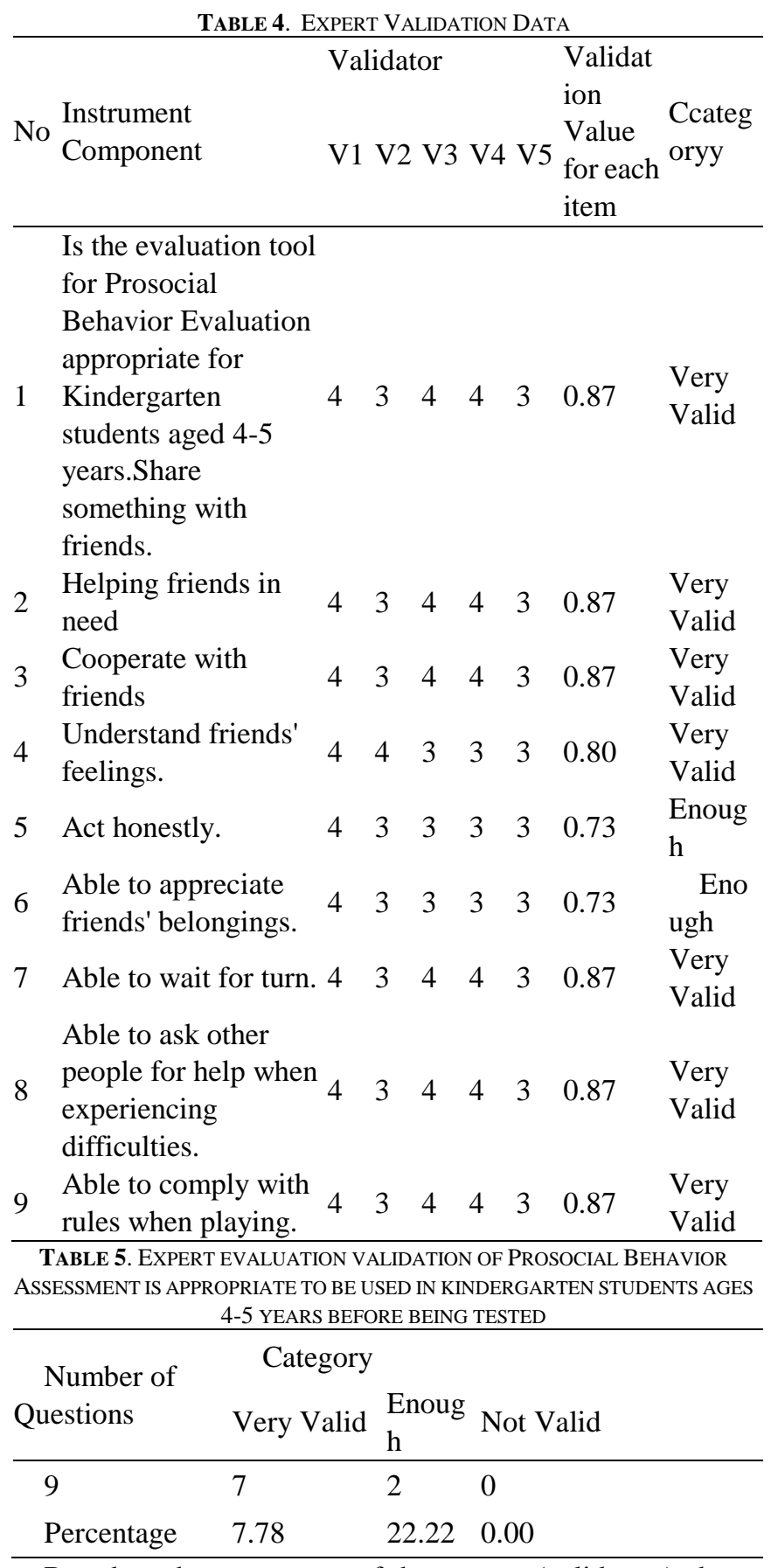

Based on the assessment of the experts (validators) about the evaluation tool of prosocial behavior assessment, it is appropriate to be used in kindergarten students aged 5-6 years. Games 1 to 9 , from 9 questions: in the very valid category 6 questions $77.78 \%$, in the valid category 2 questions $22.22 \%$ and in the category invalid 0 questions $0 \%$.

TABLE 6 RESULTS OF A SMALL GROUP TRIAL OF LEARNING IMPLEMENTATION OBSERVATION IN APPLYING THE CE2IP LEARNING MODEL TO IMPROVE PROSOCIAL SKILLS.

\begin{tabular}{|c|c|c|c|c|c|c|c|c|c|c|}
\hline \multirow[t]{2}{*}{ No } & \multicolumn{10}{|c|}{ Name of Rated aspect } \\
\hline & Children & A & B & $\mathrm{C}$ & $\mathrm{D}$ & $\mathrm{E}$ & $\mathrm{F}$ & $\mathrm{G}$ & $\mathrm{H}$ & I \\
\hline 1 & $\mathrm{Lu}$ & 4 & 3 & 4 & 3 & 4 & 3 & 4 & 4 & 4 \\
\hline 2 & $\mathrm{Fa}$ & 4 & 4 & 4 & 3 & 4 & 3 & 3 & 4 & 4 \\
\hline 4 & $\mathrm{Ma}$ & 4 & 4 & 4 & 3 & 3 & 3 & 3 & 3 & 4 \\
\hline 4 & $\mathrm{Ka}$ & 4 & 3 & 4 & 3 & 3 & 4 & 3 & 3 & 4 \\
\hline 5 & Kha & 4 & 3 & 4 & 3 & 4 & 4 & 4 & 3 & 4 \\
\hline
\end{tabular}

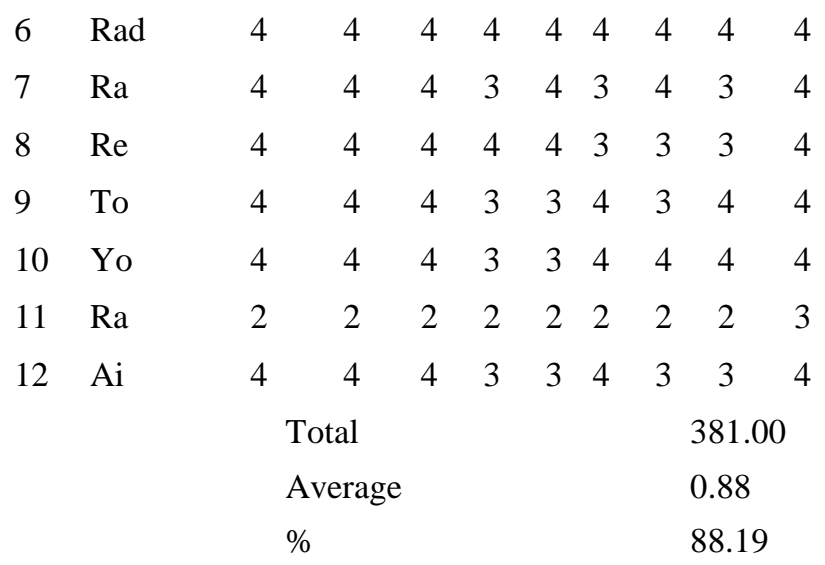

TABLE 7 RESULTS OF A LARGE GROUP TRIAL OF LEARNING IMPLEMENTATION OBSERVATION IN APPLYING THE CE2IP LEARNING MODEL TO IMPROVE PROSOCIAL SKILLS, BUTTERFLY GROUP.

\begin{tabular}{lllllllllll}
\hline No & $\begin{array}{l}\text { Name of } \\
\text { Children }\end{array}$ & \multicolumn{1}{c}{ Rated aspect } & B & C & D & E & F & G & H & I \\
\hline 1 & Lu & 4 & 4 & 4 & 4 & 4 & 4 & 4 & 4 & 4
\end{tabular}

$2 \mathrm{Fa}$

$4 \mathrm{Ma}$

$\begin{array}{lllllllll}4 & 4 & 4 & 4 & 4 & 4 & 3 & 4 & 4\end{array}$

$4 \mathrm{Ka}$

5 Kha

$\begin{array}{lllllllll}4 & 4 & 4 & 4 & 4 & 4 & 4 & 4 & 4\end{array}$

$\begin{array}{lllllllll}4 & 4 & 4 & 4 & 4 & 4 & 3 & 3 & 4\end{array}$

$6 \mathrm{Ra}$

$7 \quad \mathrm{Ra}$

$8 \operatorname{Re}$

9 To

10 Yo

$11 \mathrm{Ra}$

$12 \mathrm{Ai}$

$\begin{array}{lllllllll}4 & 4 & 4 & 4 & 4 & 4 & 4 & 4 & 4\end{array}$

$\begin{array}{lllllllll}4 & 4 & 4 & 4 & 4 & 4 & 4 & 4 & 4\end{array}$

$\begin{array}{lllllllll}4 & 4 & 4 & 3 & 4 & 3 & 4 & 3 & 4\end{array}$

$\begin{array}{lllllllll}4 & 4 & 4 & 4 & 4 & 4 & 4 & 3 & 4\end{array}$

$\begin{array}{lllllllll}4 & 4 & 4 & 3 & 4 & 4 & 4 & 4 & 4\end{array}$

$\begin{array}{lllllllll}4 & 4 & 4 & 4 & 4 & 4 & 4 & 4 & 4\end{array}$

$\begin{array}{lllllllll}2 & 2 & 2 & 2 & 2 & 2 & 3 & 3 & 3\end{array}$

$\begin{array}{lllllllll}4 & 4 & 4 & 4 & 4 & 4 & 4 & 3 & 4\end{array}$

Total

408.00

Average

0.94

$\%$

94.44

TABLE 8 RESULTS OF A LARGE GROUP TRIAL OF LEARNING IMPLEMENTATION OBSERVATION IN APPLYING THE CE2IP LEARNING MODEL TO IMPROVE PROSOCIAL SKILLS, BUTTERFLY GROUP, EAGLE GROUP

\begin{tabular}{lllllllllll}
\hline \multirow{2}{*}{ No } & $\begin{array}{l}\text { Name of } \\
\text { Children }\end{array}$ & \multicolumn{1}{c}{ Rated aspect } & B & C & D & E & F & G & H & I \\
\hline 1 & Al & 4 & 4 & 4 & 4 & 4 & 3 & 4 & 4 & 4 \\
2 & Ai & 4 & 4 & 4 & 4 & 4 & 4 & 4 & 4 & 4 \\
4 & Di & 4 & 4 & 4 & 3 & 3 & 3 & 4 & 4 & 4 \\
4 & Emil & 4 & 3 & 4 & 4 & 3 & 4 & 4 & 3 & 4 \\
5 & Tri & 4 & 4 & 4 & 4 & 4 & 4 & 4 & 3 & 4 \\
6 & Re & 4 & 4 & 4 & 4 & 3 & 4 & 4 & 4 & 4 \\
7 & Ke & 4 & 4 & 4 & 4 & 4 & 3 & 4 & 3 & 4 \\
8 & Ra & 4 & 3 & 4 & 4 & 3 & 3 & 4 & 3 & 4 \\
9 & Ha & 4 & 4 & 4 & 3 & 3 & 4 & 4 & 4 & 4 \\
10 & Ra & 4 & 4 & 4 & 3 & 4 & 4 & 4 & 4 & 4
\end{tabular}




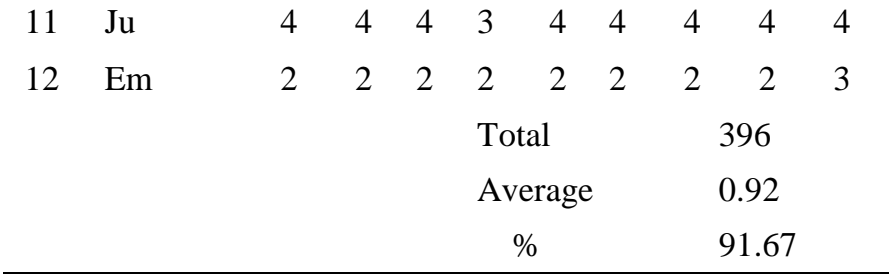

\section{CONCLUSIONS}

The play management that has been developed is needed to be reviewed for its existencen because there are several things needed to be corrected after going through the research process. Play management development to improve prosocial behavior carried out in TK Laboratory of the State University of Malang has advantages that can be used as an alternative for learning to play at TK Lab UM.

Play management development is packaged in motion learning activities through a fairly long process, starting from planning to being applied in the learning process in early childhood, resolved through several revisions to obtain a maximum learning model after going through a number of steps, ranging from expert review of learning of early childhood education, motoric experts, trials (small groups) and field tests (large groups).

The following steps above are management play to improve prosocial behavior have been developed: (1) throwing and catching ball bounce in pairs; (2) group walking moves the ball with a 1 meter wide cloth; (3) group walking moves the ball with a pipe; (4) motion running back and forth pairing geometric shapes; (5) group standing motion moves the ball from the top of the head, right side, left and bottom side; (6) Movement to throw and catch the ball along the ground in pairs.

Some suggestions include for use, dissemination, and for further development. (1) Suggestion of Utilization, New research and development in developing play management to improve prosocial behavior that can be used as one of the activities in managing play activities for children. Its use needs to consider the situation, age, and level of ability of the child. Play management aimed at group B of TK LAB UM Malang City, and can be used in other schoolsaccording to learning materials. (2) for further research and development, the suggestions are: (a) For students, in a romantic activity, it can make learning more fun and easy to do, so that, children are more enthusiastic in their activities, (b) Learning to play management helps teachers to find alternative choice activities in learning.

\section{REFERENCES}

[1] Borg and Gall. Educational Research, An Introduction. New York and London: Longman Inc. 1989.

[2] Azlina, W., \& S., Z. A,A Pilot Study: The Impact of Outdoor Play Spaces on Kindergarten Children. Procedia - Social and Behavioral Sciences, ,2012,38,pp 275-283.

[3] Elvira, M., Caroli, D., \& Sagone, E. Belief in a just world , prosocial behavior, and moral disengagement in adolescence. Procedia - Social and Behavioral Sciences,2014, 116,pp 596-600.

[4] Jongbloed-pereboom, M., Janssen, A. J. W. M., Steenbergen, B., \& Sanden, M. W. G. N. Der. Neuroscience and Biobehavioral Reviews Motor learning and working memory in children born preterm: A systematic review. Neuroscience and Biobehavioral Reviews,2012,36(4),pp1314-1330.
[5] Kılıçgün, M. Y. The Games 3-6 Aged Children's Wish to Play in the School Garden. Procedia - Social and Behavioral Sciences, 2014,152(42189),pp233-240.

[6] Lamm, C. The role of shared neural activations, mirror neurons, and morality in empathy - A critical comment,2015,90,pp15-24.

[7] Llorca-mestre, A., Malonda-vidal, E., \& Samper-garcía, P, The European Journal of Psychology Applied to Legal Context. The European Journal of Psychology Applied to Legal Context,2017, 9(2), pp 65-73.

[8] Michalska, K. J., Kinzler, K. D., \& Decety, J. Developmental Cognitive Neuroscience Age-related sex differences in explicit measures of empathy do not predict brain responses across childhood and adolescence. Accident Analysis and Prevention, 2013,3,pp 22-32.

[9] Oncu, E. C., \& Unluer, E. Preschool children's using of play materials creatively. Procedia - Social and Behavioral Sciences, 2010,2(2),pp 4457-4461.

[10] Ramazan, O., Ozdemir, A. A., \& Beceren, B. O, Evaluation of Play from Private and Public Pre-School Children's Point of View. Procedia - Social and Behavioral Sciences, 2012,46, pp 2852-2856.

[11] Stern, J. A., \& Cassidy, J. Empathy from infancy to adolescence : An attachment perspective on the development of individual differences. Developmental Review, 2018,47, pp 1-22.

\section{Author Profile}

I am Pramono, currently I am affiliated with Malang State University, Email: pramono.fip@um.ac.id

I am Nurhasan, currently I am affiliated with Surabaya State University

I am Nining Widyah Kusnanik, currently I am associated with Surabaya State University

I am Sudarsini, currently I am associated with Malang State University 